\title{
Quantification of Elemental Contaminants in Unregulated Water across Western Navajo Nation
}

\author{
Jonathan Credo ${ }^{1}$, Jaclyn Torkelson ${ }^{2}$, Tommy Rock ${ }^{2}$ and Jani C. Ingram ${ }^{2, *}$ \\ 1 College of Medicine Clinical Translational Science Graduate Program, University of Arizona, \\ Tucson, AZ 85721, USA \\ 2 Department of Chemistry \& Biochemistry, Northern Arizona University, P.O. Box 5698, \\ Flagstaff, AZ 86011, USA \\ * Correspondence: jani.ingram@nau.edu
}

Received: 11 June 2019; Accepted: 27 July 2019; Published: 31 July 2019

\begin{abstract}
The geologic profile of the western United States lends itself to naturally elevated levels of arsenic and uranium in groundwater and can be exacerbated by mining enterprises. The Navajo Nation, located in the American Southwest, is the largest contiguous Native American Nation and has over a 100-year legacy of hard rock mining. This study has two objectives, quantify the arsenic and uranium concentrations in water systems in the Arizona and Utah side of the Navajo Nation compared to the New Mexico side and to determine if there are other elements of concern. Between 2014 and 2017, 294 water samples were collected across the Arizona and Utah side of the Navajo Nation and analyzed for 21 elements. Of these, 14 elements had at least one instance of a concentration greater than a national regulatory limit, and six of these ( $\mathrm{V}, \mathrm{Ca}, \mathrm{As}, \mathrm{Mn}, \mathrm{Li}$, and $\mathrm{U})$ had the highest incidence of exceedances and were of concern to various communities on the Navajo Nation. Our findings are similar to other studies conducted in Arizona and on the Navajo Nation and demonstrate that other elements may be a concern for public health beyond arsenic and uranium.
\end{abstract}

Keywords: unregulated water; Navajo; arsenic; uranium; manganese

\section{Introduction}

The geology of the Four Corners region of the American Southwest is comprised of a sandstone and limestone bedrock with an iron-oxide and iron-sulfide mineralite matrix that contains an abundance of natural resources, including coal, copper, uranium, and vanadium [1-3]. For this reason, mining in the Four Corners region has been ongoing for the past 100 years and has left a legacy of widespread environmental contamination, affecting groundwater and soil near mine features. In addition to contamination from mining and ore refining, the iron-oxide and iron-sulfide mineralite matrix present an added hazard due to their association with heavy arsenic concentrations [4,5]. Natural arsenic is bound loosely through ionic interactions with a variety of mineralites, including iron-oxides and iron-sulfides, which can be released into the surrounding environment. Mining practices expedite this process by bringing ores closer to the surface and increasing the surface area of these iron-arsenic species, as well as concentrating waste through tailing piles and run-off $[6,7]$.

Rural and tribal communities are particularly vulnerable to environmental contamination due to a lack of public infrastructure, insufficient medical facilities, and low socioeconomic status [8,9]. Additionally, a higher density of large-scale mining and refining operations are found in these communities, which increases the risk of exposure and contamination [10-12]. One example is the Navajo Nation, located within the Four Corners region of the American Southwest. From 1944 through 1986, the Navajo Nation was the largest producer of domestic uranium ore in the United States, primarily for use in nuclear munitions during the Cold War [13-16]. Uranium mining exposures have 
been directly linked to an increase in lung and other uranium related cancers in miners and their families $[14,17,18]$. Though uranium mining ceased on the Navajo Nation in 1986, the contamination left from these operations still represents a significant danger to the Navajo people [16,19]. Unregulated "Livestock Only" water sources found across the Navajo Nation are susceptible to contamination from previous mining operations, and their unregulated nature can result in an exceedance of various United States Environmental Protection Agency (EPA) Maximum Contamination Levels (MCL) [20-23]. These unregulated water sources often represent the most convenient source of water for human consumption, household use, and watering crops for families and communities across the Navajo Nation. In many cases, the closest regulated water source for water hauling is at least an hour's drive [12].

Both arsenic and uranium's health effects from ingestion of contaminated drinking water have been widely established. Arsenic is recognized as a known carcinogen and has been demonstrated to cause vascular damage like that seen in chronic heart disease. Additionally, studies have demonstrated that arsenic can play a significant role in the development of chronic diseases by acting as a potentiating agent in concert with other contaminants [24-27]. Uranium as a contaminant in drinking water has been demonstrated to accumulate in the kidneys causing progressive kidney damage, which can lead to renal compromise or compound kidney damage related to diabetes. Its link to cancer, especially with Navajo uranium miners, was primarily tied to inhalation of uranium dust and radioactivity $[7,28,29]$.

Numerous papers have reported that both arsenic and uranium frequently exceed the EPA's MCLs in unregulated water sources on the Navajo Nation [30-33]. These studies further demonstrated that arsenic contamination is more widespread than that of uranium contamination. In one study by Hund and colleagues, they showed that there is a strong association between arsenic and uranium and suggested the existence of a belt of contamination running north to south down the central portion the Navajo Nation [34]. Although a plethora of studies and information exist on arsenic and uranium contamination on the New Mexico side of the Navajo Nation, the same scale of information does not exist on the Arizona or Utah side. In these regions, studies have focused on specific areas of the Navajo Nation, while leaving the surrounding areas as an unknown. Furthermore, water quality studies on Navajo thus far have focused primarily on arsenic and uranium contamination. There has been recent interest in ascertaining the possible contamination of unregulated water systems on the Arizona and Utah side of the Navajo Nation from other common contaminants, including copper, lead, manganese, and mercury, as part of studies to determine the risks of possible future uranium mining around the Grand Canyon [35,36]. This paper seeks to address two questions- the first is to determine if arsenic and uranium contamination is as widespread on the Arizona and Utah side of the Navajo Nation as demonstrated on the New Mexico side, and second to quantify the extent of other possible elemental contamination that may exist. The information presented in this paper will serve to provide information to Navajo Nation leaders, as well as affected communities, on the quality of contamination of their water systems and will serve as baseline information for elements that, up to this point, have not been fully explored.

\section{Materials and Methods}

\subsection{Study Area}

The Navajo Nation is the largest contiguous Native American reservation in the continental United States. Located within the Four Corners region of the American Southwest, its borders span 71,000 square kilometers across Arizona, New Mexico, and Utah. The Navajo Nation is recognized by the United States' government as a sovereign nation, though the United States retains plenary power and is separated into 110 tribal Chapters governed through five management Agencies: Chinle (14 Chapters), Crownpoint/Eastern (31 Chapters), Ft. Defiance (27 Chapters), Shiprock (20 Chapters), Tuba City/Western (18 Chapters). The Navajo Nation is within the Colorado Plateau region where the climate is largely controlled by orographic effects and elevation. Areas below $1370 \mathrm{~m}(4500 \mathrm{ft})$ are 
semiarid. The average precipitation is 20 to $30 \mathrm{~cm}$ on average per year. However, some lowland areas may receive less than eight centimeters of precipitation per year. Most of the Navajo Nation is in a rain shadow where much of the precipitation comes from the south and is blocked by the southern rim of the Colorado Plateau. Up to $65 \%$ of the yearly precipitation occurs during the late summer months (July and August) and can result in flash flooding. All runoff goes to the Colorado River, either directly or via one of the tributaries (the San Juan and the Little Colorado Rivers) [37].

In the western portion of the Navajo Nation, rocks from the Cretaceous Dakota formation and below are present. However, regional erosion patterns have resulted in progressively older rocks being exposed at the surface in the southwest portion of the Navajo Nation [38]. Recharge of the aquifers occurs in upland areas, which divide the land into separate hydrologic basins. There are five distinct hydrologic basins, which are Black Mesa, San Juan, Blanding, Henry, and Kaiparowits. Water that is recharged in the upland areas moves downward towards the major rivers and tributaries [37].

The main sources of groundwater for the Navajo Nation come from the Navajo $(\mathrm{N})$ aquifer, the Coconino (C) aquifer, and shallow alluvium aquifers [37]. The $\mathrm{N}$ aquifer is an important groundwater source in areas north of the Little Colorado River, and water quality is considered relatively good except in areas where past uranium mining and milling occurred [39]. Formations of the $\mathrm{N}$ aquifer include the Jurassic Navajo Sandstone, Kayenta Formation, and Lukachukai Member of the Wingate Sandstone. These formations are hydraulically connected and act as a single aquifer [40]. The $\mathrm{N}$ aquifer receives recharge in areas near Shonto where Navajo Sandstone is exposed at the surface. In other parts of Black Mesa, the N aquifer has overlying confining layers, which limit recharge [41]. Groundwater that is recharged near Shonto flows radially in the southwest direction to Tuba City, as well as to the south and east [40].

The $\mathrm{C}$ aquifer is an important groundwater source south of the Little Colorado River. North of the river, the $C$ aquifer is too deep to access, and the high level of salinity (total dissolved solids) make it undesirable to use for a drinking water source [39]. The $C$ aquifer includes the Pennsylvanian and Permian Upper and Middle Supai Formations, the Permian Coconino Sandstone, and the Permian Kaibab and Schnebly Hill Formations [42].

The map in Figure 1 displays the borders of the Navajo Nation and outlines the study area. Samples included in this study are represented in yellow and previous sampling efforts by the Centers for Disease Control and Prevention (CDC), the United States' Environmental Protection Agency (EPA), and Army Corps of Engineers are also provided [43]. Abandoned uranium mines are displayed in this map, represented by circles of differing size, color, and score based on EPA's Hazard Ranking System used for assessing a contaminated site's position on the National Priorities List. Locations with a higher score (i.e., 17,640) are larger and darker and deemed to pose a greater threat to human health [44]. The present study area was restricted to the Arizona and Utah Western, Chinle, Shiprock, and Fort Defiance Navajo Management Agencies.

\subsection{Sample Collection}

Water samples $(n=296)$ were collected from a variety of unregulated groundwater sources accessed by windmills, troughs, springs, and water storage tanks. Samples were identified from working with the Navajo Tribal Utility Authority (NTUA) branch offices, previous surveys conducted by the U.S. Army Corps of Engineers (US EPA 2000a), along with community and chapter members. The unregulated nature of these water sources means that they are not regularly monitored for bacterial or elemental contamination and are not upheld to the same Clean Drinking Water Act standards, despite often being an important, if not the only, source of water for communities. Their unregulated designation is due to these water sources falling outside of set active management areas as defined by the Arizona Department of Water Resources and the Navajo Nation Department of Water Resources [45,46]. 


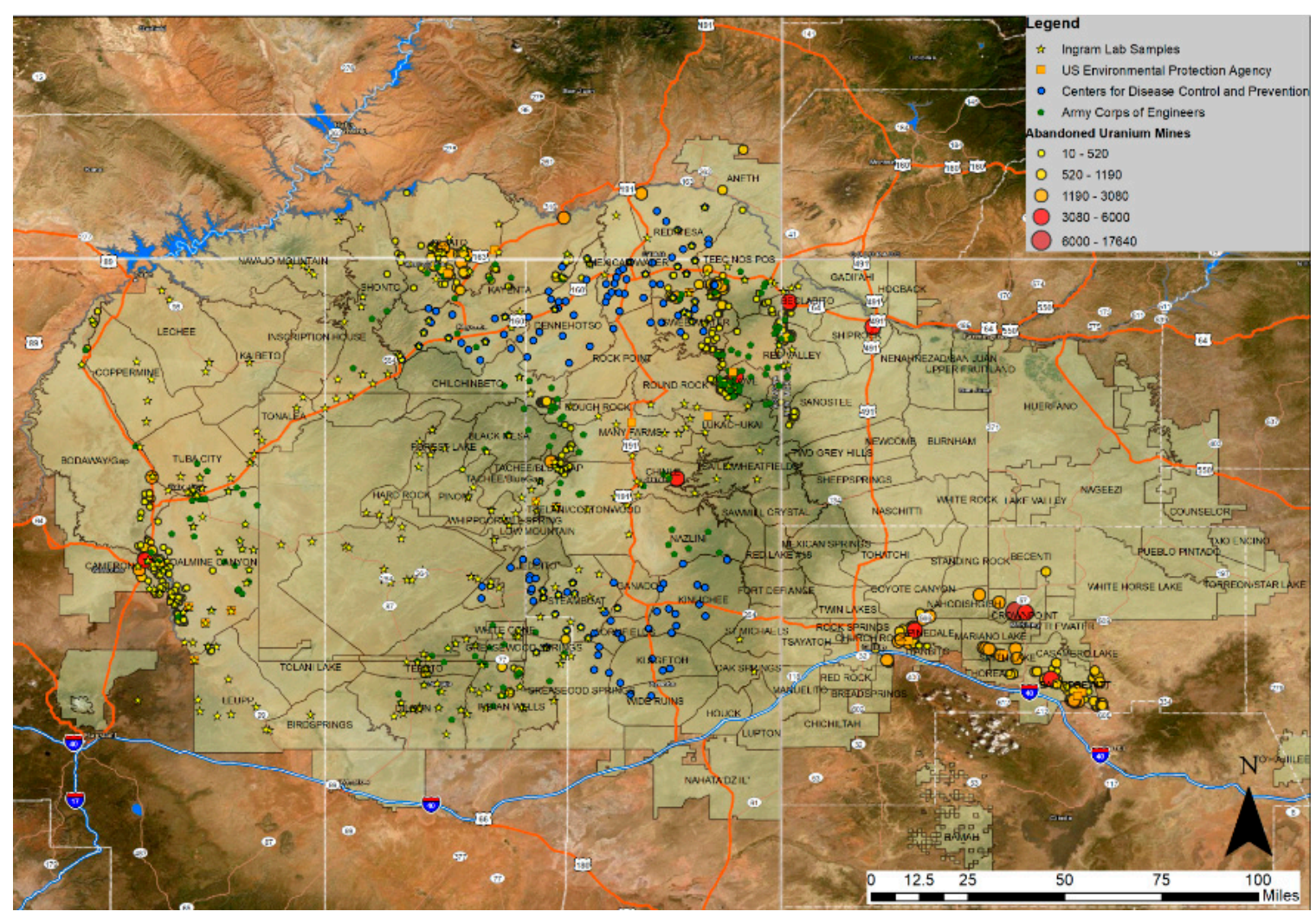

Figure 1. Map of the Navajo Nation. Sites of abandoned uranium mines are represented by circles, with larger and darker colored circles noting areas posing a greater threat to human health. Samples collected for this study $(n=296)$ are represented in yellow, denoted by the label "Ingram Lab Samples", and previous sampling efforts of government agencies are displayed in green (Army Corps of Engineers), blue (CDC), and orange (U.S. EPA). CDC: Centers for Disease Control and Prevention; EPA: Environmental Protection Agency.

Sampling was conducted during January-March and June-August of 2014, January-March of 2015, July 2016, and June and October 2017, with many sites being sampled numerous times for the evaluation of seasonal fluctuation and verification of elemental concentrations (see Supplementary Materials). Upon arrival to each site, the GPS coordinates were recorded using WGS84 Map Datum, a site description, including the presence of flora and fauna and notable features, type of water source, and site pictures were collected. An identification code was assigned to each site based on previously labeled designations, if available, the name was given by community members or readily identifiable features. Water sources were turned on and ran for one to two minutes before collection to ensure accurate representation. Water sources were not run for two minutes before collection in the presence of community members to avoid concerns regarding water waste or if water source levels were low upon visual inspection of the storage tank to avoid depleting the resource for community use. Samples for elemental analysis were filtered through a 0.45 -micron filter, preserved in nitric acid $\left(\mathrm{HNO}_{3}-\right.$ Omnipure grade) to a $\mathrm{pH}$ below 2, and sent back to Northern Arizona University (NAU) to be stored at $4{ }^{\circ} \mathrm{C}$ until analysis [47]. Samples for total mercury analysis were acid preserved in hydrochloric acid $(\mathrm{HCl})$ to a $\mathrm{pH}$ below 2 and sent back to NAU to be stored at $4{ }^{\circ} \mathrm{C}$ until digestion and analysis [48].

\subsection{Sample Analysis and Instrumentation}

The analysis was conducted by inductively coupled plasma mass spectrometry (ICP-MS) (Table 1), inductively coupled plasma optical emission spectroscopy (ICP-OES) (Table 2), flame atomic absorption (FAA), or cold vapor mercury atomic absorption (CVAA) for a variety of elements. All samples analyzed 
by ICP-MS and ICP-OES were diluted 1:10 with a dilution solution of $2 \% \mathrm{HNO}_{3}$ that contained an internal standard corresponding to the instrument and analysis method used. A Thermo Fisher Scientific X-Series 2 ICP-MS (Northern Arizona University, Flagstaff, AZ, USA) was used for all analyses with an ESI APEX HF dissolving nebulizer introduction system (Northern Arizona University, Flagstaff, AZ, USA) to produce higher sensitivity. Before each analysis, an auto-tune sequence and stage alignment were conducted followed by a manual tune for As or $U$ signals to optimize detection and maintain stability throughout the analysis. During element selection, both the most common and most stable masses were selected, and the resulting concentrations compared; lead had numerous masses selected to accurately quantitate its occurrence in the sample given the differing radiogenic origins [49,50]. To overcome the isobaric interference from the ${ }^{75} \mathrm{ArCl}$ polyatomic species and produce accurate arsenic detection, an internal correction equation was programed on the ICP-MS utilizing ${ }^{77} \mathrm{ArCl},{ }^{82} \mathrm{Se},{ }^{83} \mathrm{Kr}$ signals [51]. To further limit isobaric interferences of polyatomic ions and optimize detection, analysis on the ICP-MS was separated into "light" and "heavy" elements for analysis. ICP-OES analysis was conducted with a Perkin-Elmer Optical Emission Spectrometer Optima 4300 DV (Northern Arizona University, Flagstaff, AZ, USA) with standard plasma settings and 2-point background correction. To overcome spectral interferences from overlapping emission lines, the analysis was split into two separate methods.

Table 1. Summary of ICP-MS (inductively coupled plasma mass spectrometry) Analysis.

\begin{tabular}{cccc}
\hline \multicolumn{4}{c}{ ICP-MS Analysis } \\
\hline Element & Mass & Internal Standard & Light or Heavy \\
\hline $\mathrm{Cr}$ & 52 & $\mathrm{Rh}$ & Light \\
\hline $\mathrm{Ni}$ & 58,60 & $\mathrm{Rh}$ & Light \\
\hline $\mathrm{As}$ & 75 & $\mathrm{Ir}$ & Heavy \\
\hline $\mathrm{Mo}$ & 95,98 & $\mathrm{Rh}$ & Light \\
\hline $\mathrm{Cd}$ & 111,114 & $\mathrm{Ir}$ & Heavy \\
\hline $\mathrm{Sn}$ & 118,120 & $\mathrm{Ir}$ & Heavy \\
\hline $\mathrm{Sb}$ & 121 & $\mathrm{Rh}$ & Light \\
\hline $\mathrm{Pb}$ & $206,207,208$ & $\mathrm{Ir}$ & Heavy \\
\hline $\mathrm{U}$ & 238 & $\mathrm{Ir}$ & Heavy
\end{tabular}

Table 2. Summary of ICP-OES (inductively coupled plasma optical emission spectroscopy) Analysis.

\begin{tabular}{cccc}
\hline \multicolumn{4}{c}{ ICP-OES Analysis } \\
\hline Element & Wavelength $(\mathbf{n m})$ & Axial or Radial & Internal Standard \\
\hline $\mathrm{Ba}$ & 455.403 & Radial & $\mathrm{Y}$ \\
\hline $\mathrm{Be}$ & 313.042 & Radial & $\mathrm{Y}$ \\
\hline $\mathrm{Cu}$ & 325.747 & Radial & $\mathrm{Y}$ \\
\hline $\mathrm{Fe}$ & 259.933 & Radial & $\mathrm{Y}$ \\
\hline $\mathrm{Mn}$ & 257.604 & Radial & $\mathrm{Y}$ \\
\hline $\mathrm{V}$ & 292.399 & Radial & $\mathrm{Y}$ \\
\hline $\mathrm{Zn}$ & 213.855 & Axial & $\mathrm{Y}$ \\
\hline
\end{tabular}

A Perkin Elmer Analyst 200 Flame Atomic Absorption Spectrometer (Northern Arizona University, Flagstaff, AZ, USA) with standard operating settings was used to determine total calcium in collected samples. Samples were diluted either 1:10 or 1:100 with a $2 \% \mathrm{HNO}_{3}$ solution. Also, an aliquot of both lanthanum nitrate and cesium chloride were added as matrix modifiers and ionic suppressants to a 
final concentration of $1000 \mathrm{mg} / \mathrm{L}$. Similar quality assurance and quality control methods from ICP-MS and ICP-OES analysis were applied to FAA analysis [52].

To evaluate total mercury in the samples, a Perkin-Elmer FIMS 100 Cold Vapor Mercury Analyzer (Northern Arizona University, Flagstaff, AZ, USA) with standard operating settings and procedures was used. Field samples were digested with an aliquot of $1 \mathrm{~mL} 5 \%(\mathrm{w} / \mathrm{v}) \mathrm{KMnO}_{4}$ in $0.1 \% \mathrm{HCl}$ and placed in an $80{ }^{\circ} \mathrm{C}$ water bath for an hour. Before analysis, hydroxylamine hydrochloride and an antifoaming agent were added to quench excess $\mathrm{KMnO}_{4}$. To ensure quality assurance and quality control, a lab standard and certified reference material were run alongside the samples [53].

\subsection{Quality Assurance/Quality Control}

To ensure accuracy of the analysis, a National Institute of Standards and Technology Standard Reference Material 1640a (NIST 1640a), field and instrument blanks, and check standards were analyzed alongside the samples and were periodically re-analyzed throughout all analyses. Additionally, a split subset of 121 samples were sent to two separate laboratories, the Arizona Laboratory for Emerging Contaminants at the University of Arizona in Tucson, Arizona and the University of New Mexico's Analytical Chemistry Laboratory in Albuquerque, New Mexico, to have 20 of the investigated elements analyzed to compare the analysis conducted at NAU.

\section{Results and Discussion}

Water samples from unregulated sources on the Navajo Nation were sampled from 2013 through 2017 and were analyzed for 21 elements by ICP-MS, ICP-OES, FAA, and CVAA. The concentrations of each element were compared to US EPA MCLs [20,54] and US national averages reported by Agency for Toxic Substances and Disease Registry (ATSDR) [55], United States Geological Society (USGS) [56], the World Health Organization [57], and Morr [58]. Although these national regulatory guidelines are for regulated and treated drinking-water supplies, these limits serve as an appropriate basis for comparison for unregulated and untreated water used for human consumption. Table 3 displays the total number of samples for each element that had a reported value that exceeded, approached, was below the guidelines, or below detection (BD) by the method used (see Supplementary Materials). A sample was "approaching" a limit if its concentration was within $75 \%$ of the reported regulatory limit or national average, which has been suggested as a precautionary guideline to monitor water resources [59-64].

Of the elements analyzed, only 14 elements had samples that had at least one instance of a concentration greater than either a national regulatory limit or national averages (Table 3). Of these 14 elements, six ( $\mathrm{V}, \mathrm{Ca}, \mathrm{As}, \mathrm{Mn}, \mathrm{Li}$, and $\mathrm{U}$ ) were selected to expand upon either because of many samples had concentrations greater than a guideline or based on the risk of detrimental human health impacts [55].

For arsenic analysis, 296 sites were visited, and 61 sites were dry; and for uranium analysis, 297 sites were visited, and 66 sites were dry. Of the remaining sites, these were sampled at least twice, the results from the analysis combined, and the averages reported (Table 4). The other 19 elements were conducted on a subset of 121 or 124 samples, which were also surveyed at least twice, and the averages of the analysis reported (Table 4). On comparing the averages to the guidelines, we found that $\mathrm{V}, \mathrm{Ca}$, and Mn concentrations were above these limits, As and Li were approaching, and U was below. All the elements, except for $\mathrm{Hg}$, had an outlier with a concentration value that exceeded the guideline (Table 4). The effect of evaporation, different water storage containers, seasonal variability, and other variables likely influence the concentration of the contaminants and warrants further investigation.

Vanadium had the greatest number above comparative guidelines at 97 of 121 samples collected, whereas $U$ had the lowest prevalence of samples above comparative guidelines at 21 of 231 samples collected (Table 3). To ascertain if these six elements were associated with specific regions on the Navajo Reservation, the results were separated by the four agencies from which the samples were collected: Chinle, Fort Defiance, Shiprock, and Western Agency (Table 5). Fort Defiance and Western 
Agency had the highest exceedances for As, U, and V. Chinle and Western Agency had the highest exceedances for $\mathrm{Ca}, \mathrm{Li}$, and $\mathrm{Mn}$.

Table 3. List of 21 elements analyzed by ICP-MS (inductively coupled plasma mass spectrometry) and several samples categorized concerning guidelines. Guideline sources: US EPA (Environmental Protection Agency) Unregulated Contaminant Monitoring Rule (UCMR) [65]; United States Geological Society (USGS) [56]; Morr (2006) [58]; US EPA Maximum Contaminant Level (MCL) [20]; US EPA Regional Screening Levels (RSL) [66]; US EPA National Secondary Drinking Water Regulations (NSDWR) [54]; US EPA Drinking Water Standards and Health Advisories (DWSHA) [67]; Agency for Toxic Substances and Disease Registry (ATSDR) [55]; World Health Organization (WHO) [57]; US EPA Maximum Contaminant Level Goal (MCLG) [20]; US EPA Action Limit (AL) [20]. * Lower limit was used for comparison.

\begin{tabular}{|c|c|c|c|c|c|c|c|}
\hline Element & Guideline & $\begin{array}{l}\text { Source of } \\
\text { Guideline }\end{array}$ & Above & Approaching & Below & $\begin{array}{l}\text { Below } \\
\text { Detect }\end{array}$ & $\begin{array}{c}\text { Total Water } \\
\text { Sources Sampled }\end{array}$ \\
\hline $\mathrm{V}$ & $21.0 \mu \mathrm{g} / \mathrm{L}$ & US EPA UCMR & 97 & 2 & 18 & 4 & 121 \\
\hline $\mathrm{Ca}$ & $21.8 \mathrm{mg} / \mathrm{L}$ & USGS and Morr & 69 & 4 & 51 & 0 & 124 \\
\hline As & $10 \mu \mathrm{g} / \mathrm{L}$ & US EPA MCL & 40 & 6 & 157 & 32 & 235 \\
\hline Mn & $50 \mu \mathrm{g} / \mathrm{L}$ & $\begin{array}{l}\text { US EPA } \\
\text { NSDWR }\end{array}$ & 29 & 1 & 91 & 0 & 121 \\
\hline $\mathrm{Li}$ & $40 \mu \mathrm{g} / \mathrm{L}$ & US EPA RSL & 56 & 15 & 50 & 0 & 121 \\
\hline $\mathrm{U}$ & $30 \mu \mathrm{g} / \mathrm{L}$ & US EPA MCL & 21 & 10 & 179 & 21 & 231 \\
\hline $\mathrm{Al}$ & $50-200 \mu \mathrm{g} / \mathrm{L}^{*}$ & $\begin{array}{l}\text { US EPA } \\
\text { NSDWR }\end{array}$ & 13 & 3 & 105 & 0 & 121 \\
\hline Mo & $80 \mu \mathrm{g} / \mathrm{L}$ & $\begin{array}{l}\text { US EPA } \\
\text { DWSHA }\end{array}$ & 7 & 3 & 103 & 11 & 124 \\
\hline $\mathrm{Sr}$ & $4 \mathrm{mg} / \mathrm{L}$ & $\begin{array}{l}\text { US EPA } \\
\text { DWSHA }\end{array}$ & 7 & 4 & 110 & 0 & 121 \\
\hline $\mathrm{Fe}$ & $300 \mu \mathrm{g} / \mathrm{L}$ & $\begin{array}{l}\text { US EPA } \\
\text { NSDWR }\end{array}$ & 4 & 6 & 110 & 1 & 121 \\
\hline $\mathrm{Ni}$ & $3-10 \mu \mathrm{g} / \mathrm{L}^{*}$ & ATSDR & 3 & 16 & 100 & 5 & 124 \\
\hline Sn & $1.1-2.2 \mu \mathrm{g} / \mathrm{L}^{*}$ & WHO & 1 & 5 & 19 & 99 & 124 \\
\hline $\mathrm{Be}$ & $4 \mu \mathrm{g} / \mathrm{L}$ & US EPA MCL & 1 & 0 & 42 & 78 & 121 \\
\hline $\mathrm{Cd}$ & $5 \mu \mathrm{g} / \mathrm{L}$ & US EPA MCL & 1 & 0 & 9 & 114 & 124 \\
\hline $\mathrm{Zn}$ & $5 \mathrm{mg} / \mathrm{L}$ & $\begin{array}{l}\text { US EPA } \\
\text { NSDWR }\end{array}$ & 0 & 1 & 120 & 0 & 121 \\
\hline $\mathrm{Hg}$ & $2 \mu \mathrm{g} / \mathrm{L}$ & US EPA MCL & 0 & 0 & 124 & 0 & 124 \\
\hline $\mathrm{Cu}$ & $1.3 \mathrm{mg} / \mathrm{L}$ & US EPA MCLG & 0 & 0 & 121 & 0 & 121 \\
\hline $\mathrm{Ba}$ & $2 \mathrm{mg} / \mathrm{L}$ & US EPA MCL & 0 & 0 & 121 & 0 & 121 \\
\hline $\mathrm{Cr}$ & $100 \mu \mathrm{g} / \mathrm{L}$ & US EPA MCL & 0 & 0 & 105 & 19 & 124 \\
\hline $\mathrm{Sb}$ & $6 \mu \mathrm{g} / \mathrm{L}$ & US EPA MCL & 0 & 0 & 106 & 18 & 124 \\
\hline $\mathrm{Pb}$ & $15 \mu \mathrm{g} / \mathrm{L}$ & US EPA AL & 0 & 0 & 78 & 46 & 124 \\
\hline
\end{tabular}

A combination of a long history of hard rock mining, limited water infrastructure, and a natural geologic profile high in metal and metalloid species increases the potential for drinking water contamination on the Navajo Nation. An added factor for concern is that as much as 30\% of those living on the Navajo Nation get their drinking water from unregulated sources [68]. The results presented in this study demonstrated that there are comparable levels of arsenic in unregulated water resources to rural communities across the United States [5,69]. Arsenic was detected at concentrations greater than the US EPA MCL of $10 \mu \mathrm{g} / \mathrm{L}$ in $17 \%$ (40 out of 235) of sampled sites. Welch and colleagues found slightly less than half of 30,000 arsenic analyses of groundwater in the United States at $1 \mu \mathrm{g} / \mathrm{L}$ and 
about $10 \%$ exceeded $10 \mu \mathrm{g} / \mathrm{L}$ [5]. However, arsenic concentrations greater than $10 \mu \mathrm{g} / \mathrm{L}$ were more frequently observed in the western United States than in the eastern half. Looking specifically at Arizona and the Navajo Nation, these results reveal comparable concentrations and incidences of regulatory infractions for elemental contaminants, especially arsenic [31,70]. Jones and colleagues utilized public water databases to quantify arsenic concentrations across Arizona and found that rural areas and those associated with mining ventures had arsenic in water systems at similar concentrations to those represented in this study, but it lacked information about the Navajo Nation [70]. Hoover and colleagues combined federal databases and sampling efforts by the University of New Mexico to characterize the extent of elemental contamination in drinking water across the Navajo Nation [31]. Like this study, they found elemental contamination existed across the Navajo Nation and was closely dependent on the agency where sampling was conducted. The variability of elemental contamination in water noted in this study and the Hoover study may be related to differing access to water across the Navajo Nation [31].

Table 4. List of 21 elements analyzed by ICP-MS (inductively coupled plasma mass spectrometry) reporting the maximum, minimum, average, and median values from the set of samples listed in Table 1. B.D. $=$ Below Detect.

\begin{tabular}{|c|c|c|c|c|}
\hline Element & $\operatorname{Max}(\mu \mathrm{g} / \mathrm{L})$ & $\operatorname{Min}(\mu \mathrm{g} / \mathrm{L})$ & Average ( $\mu \mathrm{g} / \mathrm{L})$ & Median $(\mu \mathrm{g} / \mathrm{L})$ \\
\hline $\mathrm{V}$ & 520 & B.D. & 81.70 & 67.30 \\
\hline $\mathrm{Ca}$ & 430 & 0.35 & 44.7 & 25.6 \\
\hline As & 190 & 0.03 & 8.21 & 1.99 \\
\hline $\mathrm{Mn}$ & 14700 & 0.10 & 164 & 3.44 \\
\hline $\mathrm{Li}$ & 630 & 3.02 & 63.3 & 37.6 \\
\hline $\mathrm{U}$ & 490 & 0.04 & 14.1 & 3.05 \\
\hline $\mathrm{Al}$ & 64600 & 2.16 & 556 & 12.1 \\
\hline Mo & 1190 & B.D. & 27.2 & 2.89 \\
\hline $\mathrm{Sr}$ & 10300 & 18.9 & 1160 & 478 \\
\hline $\mathrm{Fe}$ & 605 & 0.02 & 61.5 & 23.1 \\
\hline $\mathrm{Ni}$ & 560 & 0.02 & 6.42 & 1.09 \\
\hline Sn & 2.50 & 0.01 & 0.53 & 0.40 \\
\hline Be & 60.3 & B.D. & 0.50 & 0.00 \\
\hline $\mathrm{Cd}$ & 11.1 & 0.01 & 0.30 & 0.05 \\
\hline $\mathrm{Zn}$ & 3900 & 3.38 & 197 & 48.1 \\
\hline $\mathrm{Hg}$ & B.D. & B.D. & B.D. & B.D. \\
\hline $\mathrm{Cu}$ & 26.0 & 0.02 & 2.80 & 1.21 \\
\hline $\mathrm{Ba}$ & 1200 & 7.91 & 177 & 93.7 \\
\hline $\mathrm{Cr}$ & 12.1 & 0.03 & 0.94 & 0.47 \\
\hline $\mathrm{Sb}$ & 2.80 & 0.03 & 0.33 & 0.27 \\
\hline $\mathrm{Pb}$ & 9.25 & 0.02 & 0.66 & 0.10 \\
\hline
\end{tabular}


Table 5. Distribution of As, U, V, Mn, Ca, and Li concerning guideline comparisons across the Chinle, Fort Defiance, Shiprock, and Western Agencies. B.D. = Below Detect.

\begin{tabular}{|c|c|c|c|c|c|c|}
\hline \multirow[b]{2}{*}{ Element } & \multirow[b]{2}{*}{ Guideline } & \multicolumn{4}{|c|}{ Agency } & \multirow[b]{2}{*}{ Totals } \\
\hline & & Chinle & Fort Defiance & Shiprock & Western & \\
\hline \multirow{5}{*}{ Arsenic } & Above & 3 & 23 & 3 & 11 & 40 \\
\hline & Approaching & 0 & 4 & 0 & 2 & 6 \\
\hline & Below & 31 & 29 & 10 & 89 & 159 \\
\hline & B.D. & 11 & 2 & 2 & 15 & 30 \\
\hline & Totals & 45 & 58 & 15 & 117 & 235 \\
\hline \multirow{5}{*}{ Uranium } & Above & 3 & 7 & 1 & 7 & 18 \\
\hline & Approaching & 3 & 3 & 0 & 5 & 11 \\
\hline & Below & 32 & 44 & 14 & 93 & 183 \\
\hline & B.D. & 6 & 2 & 0 & 11 & 19 \\
\hline & Totals & 44 & 56 & 15 & 116 & 231 \\
\hline \multirow{5}{*}{ Vanadium } & Above & 24 & 26 & 7 & 40 & 97 \\
\hline & Approaching & 0 & 0 & 0 & 2 & 2 \\
\hline & Below & 5 & 1 & 1 & 11 & 18 \\
\hline & B.D. & 2 & 2 & 0 & 0 & 4 \\
\hline & Totals & 31 & 29 & 8 & 53 & 121 \\
\hline \multirow{5}{*}{ Manganese } & Above & 19 & 4 & 1 & 5 & 29 \\
\hline & Approaching & 1 & 0 & 0 & 0 & 1 \\
\hline & Below & 12 & 25 & 7 & 47 & 91 \\
\hline & B.D. & 0 & 0 & 0 & 0 & 0 \\
\hline & Totals & 32 & 29 & 8 & 52 & 121 \\
\hline \multirow{5}{*}{ Calcium } & Above & 26 & 11 & 1 & 31 & 69 \\
\hline & Approaching & 0 & 0 & 0 & 4 & 4 \\
\hline & Below & 8 & 18 & 6 & 19 & 51 \\
\hline & B.D. & 0 & 0 & 0 & 0 & 0 \\
\hline & Totals & 34 & 29 & 7 & 54 & 124 \\
\hline \multirow{5}{*}{ Lithium } & Above & 19 & 13 & 5 & 19 & 56 \\
\hline & Approaching & 6 & 5 & 1 & 3 & 15 \\
\hline & Below & 6 & 12 & 2 & 30 & 50 \\
\hline & B.D. & 0 & 0 & 0 & 0 & 0 \\
\hline & Totals & 31 & 30 & 8 & 52 & 121 \\
\hline
\end{tabular}

Beyond arsenic and uranium, the results demonstrate an elevation above US EPA guidelines and USGS average water content of four other metals (Ca, Li, Mn, V). These four metals have been investigated in only a few previous publications, the most significant being a spatial clustering analysis by Hoover (2018) that matched co-eluting contaminants in water sources across Navajo [52,71,72]. Elevations of calcium and vanadium in drinking water do not seem to have any significant detriment other than changes in the aesthetic quality of the water, and these elevations seem reasonable given the geologic profile of the Navajo Nation $[56,65,73]$. Some studies suggest lithium in drinking water is associated with decreased instances of some mental health conditions (depression, anxiety, and dementia); however, this is still hotly debated. Additionally, lithium exposure has been linked with the 
development of chronic kidney disease [72,74-77]. There is growing evidence that chronic exposure to manganese in drinking water may have similar neurotoxic effects as occupational exposure to manganese, resulting in intellectual impairment in children and visible brain deposition in mouse models [78-80]. Bouchard and colleagues in 2007 conducted a pilot study investigating manganese exposure through tap water and the incidence of hyperactivity as a pathway for learning impairment in Canadian children [81]. Their results demonstrated at concentrations, like what was seen in the present study, were correlated with more cases of hyperactive behavior and outbursts during classroom settings. They followed up this study in 2011 with a cross-sectional study examining IQ scores in children and manganese exposure through water [82]. Much like their earlier study, Bouchard and colleagues found that elevated levels of manganese in drinking water seemed to correlate with decreased IQ scores, and these findings have been repeated in other studies from other groups [83-85]. While the concentrations of manganese in the Canadian schoolchildren study conducted by Bouchard were slightly higher, an average of $200 \mu \mathrm{g} / \mathrm{L}$, Bouchard asserts that the children exposed to these concentrations were not relying on these water sources as their sole supply, and it is more important to look at a cumulative dose. Compared to this study, while the median manganese concentration is lower, the lack of available water in the areas sampled in this study may have a similar cumulative effect mentioned by Bouchard and is an avenue of study that warrants further investigation. Compared to arsenic and uranium in drinking water, both of which are recognized primary drinking water contaminants, elevated levels of calcium, lithium, manganese, and vanadium are based on non-enforceable guidelines or national averages and, in the case of manganese, these limits have been abolished. Despite this, these guidelines, as with primary standards, are a metric for which to compare the drinking water concentrations. Furthermore, arguments question if the current guidelines used to create enforceable regulatory limits on drinking water are insufficient, especially given research that opposes the previous dogma and supports observable health consequences to exposed populations $[59,86]$.

\section{Conclusions}

This paper sought to address two questions- the first was to determine if arsenic and uranium contamination is as widespread on the Arizona and Utah side of the Navajo Nation as demonstrated on the New Mexico side, and second to quantify the extent of other possible elemental contamination that may exist. The results reported here have demonstrated similarities in drinking water contaminants across the Navajo Nation, the American Southwest, and the United States; they have additionally demonstrated the potential for other contaminants that may pose measurable health effects in those exposed. A hydrogeochemical approach may expound upon the findings in this study, as well as others, especially elucidating the reason why certain regions of the Navajo Nation have a similar water contamination profile despite differences in mining history and available infrastructure. Clean up of abandoned uranium mines by the US EPA and other US government entities is moving into the second Five-Year Plan [87]. This timely study contributes to the current understanding of water quality on the Navajo Nation and will help guide future policy and clean up decisions, as well as contribute to the understanding of the potential for health impacts from exposure to these contaminants.

Supplementary Materials: The following are available online at http://www.mdpi.com/1660-4601/16/15/2727/s1. Water samples and data.

Author Contributions: Conceptualization: J.C., T.R., J.I.; Methodology: J.C., J.T.; Formal Analysis: J.C.; Investigation: J.C., T.R., J.T.; Resources: J.I.; Data Curation: J.C.; Writing-Original Draft Preparation: J.C.; Writing-Review and Editing: J.C., J.T., J.I.; Supervision: J.I.; Project Administration: J.I.; Funding Acquisition: J.I.

Funding: National Institute of Environmental Health Sciences/Center for Indigenous Environmental Health Research (P50ES026089), National Cancer Institute/Native American Cancer Prevention (U54CA143925), Northwest Portland Area Indian Health Board NARCH 10 (1S06GM127164) funded by National Institutes of Health, and NARCH 7 (U261IHS0074-01-01) funded by Indian Health Service and the National Institutes of Health.

Acknowledgments: The authors thank the Navajo Nation communities and tribal leaders for their thoughtful discussions and guidance for this work. The authors also would like to thank Michael Ketterer and Martin Mihay for their technical assistance. 
Conflicts of Interest: The authors declare no conflict of interest.

\section{References}

1. Chenoweth, W.L.; Malan, R.C. The Uranium Deposits of Northeastern Arizona. 1973. Available online: https:// nmgs.nmt.edu/publications/guidebooks/downloads/24/24_p0139_p0149.pdf (accessed on 10 December 2018).

2. Chenoweth, W.L. Early Vanadium-Uranium Mining in Monument Valley, Apache and Navajo Counties, Arizona, and San Juan County, Utah. Ariz. Geol. Surv. 1985, 85-115. Available online: http://repository.azgs. az.gov/uri_gin/azgs/dlio/456 (accessed on 11 December 2018).

3. Linhoff, B.; Longmire, P.; Rearick, M.; McQuillan, D.; Perkins, G. Water quality and hydrogeochemistry of a basin and range watershed in a semi-arid region of northern New Mexico. Environ. Earth Sci. 2016, 75, 640. [CrossRef]

4. Foust, R.D., Jr.; Mohapatra, P.; Compton-O'Brien, A.-M.; Reifel, J. Groundwater arsenic in the Verde Valley in central Arizona, USA. Appl. Geochem. 2004, 19, 251-255. [CrossRef]

5. Welch, A.H.; Westjohn, D.; Helsel, D.R.; Wanty, R.B. Arsenic in Ground Water of the United States: Occurrence and Geochemistry. Ground Water 2000, 38, 589-604.

6. Njinga, R.L.; Tshivhase, V.M.; Mathuthu, M. Chemical Toxicity of Surface-Based Drinking Water Sources Due to Natural Uranium Pollutant Around Princess Gold Mine Environs in Roodepoort, South Africa. Expo. Heal. 2016, 8, 457-464. [CrossRef]

7. Winde, F. Uranium pollution of the Wonderfonteinspruit, 1997-2008 Part 1: Uranium toxicity, regional background and mining-related sources of uranium pollution. Water SA 2010, 36, 239-256.

8. Health Resources \& Services Administration. Federal Office of Rural Health Policy. Available online: https://www.hrsa.gov/rural-health/index.html (accessed on 12 February 2019).

9. Sarche, M.; Spicer, P. Poverty and Health Disparities for American Indian and Alaska Native Children: Current Knowledge and Future Prospects. Ann. N. Y. Acad. Sci. 2008, 1136, 126-136. [CrossRef]

10. Corlin, L.; Rock, T.; Cordova, J.; Woodin, M.; Durant, J.L.; Gute, D.M.; Ingram, J.; Brugge, D. Health Effects and Environmental Justice Concerns of Exposure to Uranium in Drinking Water. Curr. Environ. Heal. Rep. 2016, 3, 434-442. [CrossRef]

11. Harmon, M.E.; Lewis, J.; Miller, C.; Hoover, J.; Ali, A.-M.S.; Shuey, C.; Cajero, M.; Lucas, S.; Zychowski, K.; Pacheco, B.; et al. Residential proximity to abandoned uranium mines and serum inflammatory potential in chronically exposed Navajo communities. J. Expo. Sci. Environ. Epidemiol. 2017, 27, 365-371. [CrossRef]

12. Lewis, J.; Hoover, J.; MacKenzie, D. Mining and Environmental Health Disparities in Native American Communities. Curr. Environ. Heal. Rep. 2017, 4, 130-141. [CrossRef]

13. Alvarez, R. Uranium Mining and the U.S. Nuclear Weapons Program. Public Interest Rep. $2013,66$. Available online: https://fas.org/pir-pubs/uranium-mining-u-s-nuclear-weapons-program-3/ (accessed on 1 March 2019).

14. Brugge, D.; Goble, R. The History of Uranium Mining and the Navajo People. Am. J. Public Heal. 2002, 92, 1410-1419. [CrossRef] [PubMed]

15. Lott, J. Once upon a mine: The legacy of uranium on the Navajo Nation. Environ. Health Perspect. 2014, 122, A44-A49.

16. Fettus, G.; McKinzie, M. Nuclear Fuel's Dirty Beginnings: Environmental Damage and Public Health Risks from Uranium Mining in the American West. 2012. Available online: https://www.nrdc.org/resources/ nuclear-fuels-dirty-beginnings-environmental-damage-and-public-health-risks-uranium-mining (accessed on 14 February 2019).

17. Ball, H. Cancer Factories: American's Tragic Quest for Uranium Self-Sufficiency; Greenwood Press: Westport, CT, USA, 1993.

18. Eichstaedt, P. If You Poison Us; Red Crane Books: Santa Fe, NM, USA, 1994.

19. Ivanova, K.; Stojanovska, Z.; Badulin, V.; Kunovska, B.; Yovcheva, M. Screening for risk assessment around closed uranium mining sites. Radioprotection 2016, 51, 193-198. [CrossRef]

20. United States Environmental Protection Agency. National Primary Drinking Water Regulations; United States Environmental Protection Agency: Washington, DC, USA, 2018. 
21. Dias da Cunha, K.M.; Henderson, H.; Thomson, B.M.; Hecht, A.A. Ground water contamination with ${ }^{238}$ U, ${ }^{234} \mathrm{U},{ }^{235} \mathrm{U},{ }^{226} \mathrm{Ra}$, and ${ }^{210} \mathrm{~Pb}$ from past uranium mining: Cove wash, Arizona. Environ. Geochem. Health 2014, 36, 477-487. [CrossRef] [PubMed]

22. Murphy, M.; Barney, Y.; Begay, M.G.; Morgan, P.; Kieszak, S.; Caldwell, K.; Chang, A.; Graham, S.; McGeehin, M.; Lewis, J. Investigation of household drinking water sources and contaminant exposures in the Navajo Nation, 2008-2009. Epidemiology 2011, 22, S114. [CrossRef]

23. Orescanin, V.; Kollar, R.; Nad, K.; Mikelic, I.L.; Kollar, I. Characterization and treatment of water used for human consumption from six sources located in the Cameron/Tuba City abandoned uranium mining area. J. Environ. Sci. Health Part A 2011, 46, 627-635. [CrossRef]

24. Ferrante, M.; OliveriConti, G.; RasicMilutinovic, Z. Health Effects of Metals and Related Substances in Drinking Water; Jovanovic, D., Ed.; IWA Publishing: London, UK, 2014.

25. Hughes, M.F.; Beck, B.D.; Chen, Y.; Lewis, A.S.; Thomas, D.J. Arsenic exposure and toxicology: A historical perspective. Toxicol. Sci. 2011, 123, 305-332. [CrossRef]

26. International Agency for Research on Cancer; World Health Organization. Arsenic and Arsenic Compounds. Available online: https://monographs.iarc.fr/iarc-monographs-volume-100c-arsenic-andarsenic-compounds/ (accessed on 10 March 2019).

27. Yager, J.W.; Erdei, E.; Myers, O.; Siegel, M.; Berwick, M. Arsenic and ultraviolet radiation exposure: Melanoma in a New Mexico non-Hispanic white population. Environ. Geochem. Health 2016, 38, 897-910. [CrossRef]

28. United States Department of Health and Human Services. Toxicological Profile for Uranium; Agency for Toxic Substances and Disease Registry: Atlanta, GA, USA, 2013.

29. United States Department of Health and Human Services. Indian Health Service. 2018. Available online: https://www.ihs.gov/ (accessed on 22 January 2019).

30. De Lemos, J.L.; Brugge, D.; Cajero, M.; Downs, M.; Durant, J.L.; George, C.M.; Henio-Adeky, S.; Nez, T.; Manning, T.; Rock, T.; et al. Development of risk maps to minimize uranium exposures in the Navajo Churchrock mining district. Environ. Health 2009, 8, 29. [CrossRef] [PubMed]

31. Hoover, J.; Gonzales, M.; Shuey, C.; Barney, Y.; Lewis, J. Elevated arsenic and uranium concentrations in unregulated water sources on the Navajo Nation, USA. Expo. Health 2017, 9, 113-124. [CrossRef] [PubMed]

32. Samuel-Nakamura, C.; Robbins, W.A.; Hodge, F.S. Uranium and associated heavy metals in Ovis aries in a mining impacted area in Northwestern New Mexico. Int. J. Environ. Res. Public Health 2017, $14,848$. [CrossRef] [PubMed]

33. Wildeman, M.K. Arsenic in Hopis' water twice the EPA limit, and it may be making them sick. Republic 2016, 1. Available online: https://www.azcentral.com/story/news/local/arizona-water/2016/08/24/natural-arsenicpoisons-hopi-reservation-water/88317458/ (accessed on 5 October 2018).

34. Hund, L.; Bedrick, E.J.; Miller, C.; Huerta, G.; Nez, T.; Ramone, S.; Shuey, C.; Cajero, M.; Lewis, J. A Bayesian framework for estimating disease risk due to exposure to uranium mine and mill waste on the Navajo Nation. J. R. Statist. Soc. A 2015, 178, 1069-1091. [CrossRef]

35. Cain, D.; Croteau, M.N.; Fuller, C.; Barasch, D.; Beisner, K.; Schenk, E. Uranium exposure in spring outflows within Grand Canyon National Park. In Proceedings of the 14th Biennial Conference of Science \& Management on the Colorado Plateau \& Southwest Region, Flagstaff, AZ, USA, 11-14 September 2017.

36. Hinck, J.E.; Cleveland, D. Using ecological risk analysis to screen for health effects: Application at uranium mines. In Proceedings of the 14th Biennial Conference of Science \& Management on the Colorado Plateau \& Southwest Region, Flagstaff, AZ, USA, 11-14 September 2017.

37. Cooley, M.E.; Harshbarger, J.P.; Hardt, W.F. Regional hydrogeology of the Navajo and Hopi Indian Reservations, Arizona, New Mexico, and Utah. 1969; pp. 1-61. Available online: https:/pubs.usgs.gov/pp/ 0521a/report.pdf (accessed on 11 November 2018).

38. Peirce, H.W.; Keith, S.B.; Wilt, J.C. Arizona Geological Survey Bulletin 182-Coal, Oil, Natural Gas, Helium, and Uranium in Arizona-Plate 9. 1970. Available online: http://repository.azgs.az.gov/uri_gin/azgs/dlio/1270 (accessed on 14 July 2019).

39. Arizona Department of Water Resources. Arizona Water Atlas-Volume 2 Eastern Plateau Planning Area. 2009. Available online: http://www.azwater.gov/azdwr/StatewidePlanning/WaterAtlas/documents/Volume_ 2_final_web.pdf (accessed on 14 July 2019). 
40. Eychaner, J. Geohydrology and effects of water use in the Black Mesa area, Navajo and Hopi Indian Reservations, Arizona. 1983; pp. 1-26. Available online: https://pubs.usgs.gov/wsp/2201/report.pdf (accessed on 11 March 2019).

41. Lopes, T.J.; Hoffmann, J.P. Geochemical analyses of ground-water ages, recharge rates, and hydraulic conductivity of the N aquifer, Black Mesa area, Arizona. 1997. Available online: https://pubs.er.usgs.gov/ publication/wri964190 (accessed on 11 March 2019).

42. Bills, D.J.; Flynn, M.E.; Monroe, S.A. Hydrogeology of the Coconino Plateau and adjacent areas, Coconino and Yavapai Counties, Arizona. 2016. Available online: https://pubs.usgs.gov/sir/2005/5222/sir2005-5222_text.pdf (accessed on 11 March 2019).

43. United States Environmental Protection Agency. Navajo Nation Drinking Water Source Sampling February-March. U.S. EPA START Contractor Team 9: 2008. Available online: https://www.epa.gov/ sites/production/files/2016-06/documents/2008-08-28-navajo-drinking-water-source-sampling.pdf (accessed on 21 October 2018).

44. United States Environmental Protection Agency. Introduction to the Hazard Ranking System (HRS). Available online: https://www.epa.gov/superfund/introduction-hazard-ranking-system-hrs (accessed on 14 July 2019).

45. Arizona Department of Water Resources. Groundwater Permitting and Wells; Arizona Game and Fish Department: Phoenix, AZ, USA, 2018.

46. Navajo Nation Department of Water Resources. Navajo Nation Technical, Construction, and Operations Branch. Available online: http://www.nndwr.navajo-nsn.gov/ (accessed on 2 May 2019).

47. United States Environmental Protection Agency. Method 200.8: Determination of Trace Elements in Waters and Wastes by Inductively Coupled Plasma-Mass Spectrometry, Revision 5.4; Environmental Protection Agency: Cincinnati, OH, USA, 1994.

48. United States Environmental Protection Agency. Method 245.1: Determination of Mercury in Water by Cold Vapor Atomic Absorption Spectrometry; Revision 3.0; Environmental Protection Agency: Cincinnati, OH, USA, 1994.

49. Bower, N.W.; McCants, S.A.; Custodio, J.M.; Ketterer, M.E.; Getty, S.R.; Hoffman, J.M. Human lead exposure in a late 19th century mental asylum population. Sci. Total Environ. 2007, 373, 463-473. [CrossRef] [PubMed]

50. Robbins, N.; Zhang, Z.; Sun, J.; Ketterer, M.E.; Lalumandier, J.A.; Shulze, R.A. Childhood lead exposure and uptake in teeth in the Cleveland area during the era of leaded gasoline. Sci. Total Environ. 2010, 408, 4118-4127. [CrossRef]

51. United States Environmental Protection Agency. Method 6020B (SW-846): Inductively Coupled Plasma-Mass Spectrometry, Revision 2; IEEE Computer Society: Washington, DC, USA, 2014.

52. United States Environmental Protection Agency. Method 7000B (SW-846): Flame Atomic Absorption Spectrophotometry, Revision 2.0; IEEE Computer Society: Washington, DC, USA, 2007.

53. United States Environmental Protection Agency. Method 1631: Mercury in Water by Oxidation, Purge and Trap, and Cold Vapor Atomic Fluorescence Spectrometry; Revision, E., Ed.; IEEE Computer Society: Washington, DC, USA, 2002.

54. United States Environmental Protection Agency. Secondary Drinking Water Standards: Guidance for Nuisance Chemicals. In Drinking Water Standards and Regulations; 2017. Available online: https://www.epa.gov/dwstandardsregulations/secondary-drinking-water-standards-guidancenuisance-chemicals\#self (accessed on 4 May 2019).

55. Agency for Toxic Substances and Disease Registry (ATSDR). Toxicological Profiles; U.S. Department of Health and Human Services, Public Health Service: Atlanta, GA, USA, 2005. Available online: https: //www.atsdr.cdc.gov/toxprofiledocs/index.html (accessed on 8 February 2019).

56. United States Geological Survey. Water Hardness. Water Hardness and Alkalinity. 2016. Available online: https://water.usgs.gov/owq/hardness-alkalinity.html (accessed on 26 February 2019).

57. World Health Organization. Inorganic Tin in Drinking-Water: Background Document for Development of WHO Guidelines for Drinking-Water Quality. 2004. Available online: https:/www.who.int/water_sanitation_ health/dwq/chemicals/tin.pdf (accessed on 14 July 2019).

58. Morr, S.; Cuartas, E.; Alwatter, B.; Lane, J.M. How much calcium is in your drinking water? A survey of calcium concentrations in bottled and tap water and their significance for medical treatment and drug administration. HSS J. 2006, 2, 130-135. [CrossRef]

59. Begum, M.; Horowitz, J.; Hossain, M.I. Low-dose risk assessment for arsenic: A meta-analysis approach. Asia Pac. J. Public Health 2015, 27, 20-35. [CrossRef] 
60. Brown, V.J. Uranium in drinking water: Low dose acts as endocrine mimic. Environ. Health Perspect. 2007, 115, A595. [CrossRef]

61. Frisbie, S.H.; Mitchell, E.J.; Sarkar, B. World health organization increases its drinking-water guideline for uranium. Environ. Sci. Process. Impacts 2013, 15, 1817-1823. [CrossRef] [PubMed]

62. Medrano, M.A.; Boix, R.; Pastor-Barriuso, R.; Palau, M.; Damián, J.; Ramis, R.; Del Barrio, J.L.; Navas-Acien, A. Arsenic in public water supplies and cardiovascular mortality in Spain. Environ. Res. 2010, 110, 448-454. [CrossRef] [PubMed]

63. Raymond-Whish, S.; Mayer, L.P.; O’Neal, T.; Martinez, A.; Sellers, M.A.; Christian, P.J.; Marion, S.L.; Begay, C.; Propper, C.R.; Hoyer, P.B.; et al. Drinking water with uranium below the U.S. EPA water standard causes estrogen receptor-dependent responses in female mice. Environ. Health Perspect. 2007, 115, 1711-1716. [CrossRef] [PubMed]

64. Saint-Jacques, N.; Parker, L.; Brown, P.; Dummer, T.J. Arsenic in drinking water and urinary tract cancers: A systematic review of 30 years of epidemiological evidence. Environ. Health 2014, 13, 13-44. [CrossRef] [PubMed]

65. United States Environmental Protection Agency. The Third Unregulated Contaminant Monitoring Rule (UCMR 3): Data Summary; IEEE Computer Society: Washington, DC, USA, 2017.

66. United States Environmental Protection Agency. Regional Screening Level (RSL) Summary Table (TR = 1E 06, HQ = 1). 2019. Available online: https://www.epa.gov/risk/regional-screening-levels-rsls-generic-tables (accessed on 13 July 2019).

67. United States Environmental Protection Agency. 2018 Edition of the Drinking Water Standards and Health Advisories Tables. 2018. Available online: https://www.epa.gov/dwstandardsregulations/2018-drinkingwater-standards-and-advisory-tables (accessed on 14 July 2019).

68. United States Environmental Protection Agency. Navajo Nation: Cleaning Up Abandoned Uranium Mines. In Providing Safe Drinking Water in Areas with Abandoned Uranium Mines; 2018. Available online: https:/www.epa.gov/navajo-nation-uranium-cleanup/providing-safe-drinking-waterareas-abandoned-uranium-mines (accessed on 15 January 2019).

69. Nigra, A.E.; Sanchez, T.R.; Nachman, K.E.; Harvey, D.E.; Chillrud, S.N.; Graziano, J.H.; Navas-Acien, A. The effect of the Environmental Protection Agency maximum contaminant level on arsenic exposure in the USA from 2003 to 2014: An analysis of the National Health and Nutrition Examination Survey (NHANES). Lancet Public Health 2017, 2, 513-521. [CrossRef]

70. Jones, M.C.; Credo, J.M.; Ingram, J.C.; Baldwin, J.A.; Trotter, R.T., Jr.; Propper, C.R. Using multiple, publically available databases to create a statewide map of arsenic concentrations across Arizona. J. Contemp. Water Res. Educ. 2019. (Submitted).

71. Hoover, J.; Coker, E.; Barney, Y.; Shuey, C.; Lewis, J. Spatial clustering of metal and metalloid mixtures in unregulated water sources on the Navajo Nation-Arizona, New Mexico, and Utah, USA. Sci. Total Environ. 2018, 633, 1667-1678. [CrossRef]

72. Wirt, L.; Peter, C.; Metre, V.; Favor, B. Historical water-quality data, Puerco river basin, Arizona and New Mexico. 1991; pp. 91-196. Available online: https://pubs.er.usgs.gov/publication/ofr91196 (accessed on 2 May 2019).

73. Kelley, K.D.; Scott, C.T.; Polyak, D.E.; Kimball, B.E. Vanadium-Critical mineral resources of the United States-Economic and environmental geology and prospects for future supply. 2017, pp. U1-U36. Available online: https://pubs.er.usgs.gov/publication/pp1802 (accessed on 2 May 2019).

74. Ishii, N.; Terao, T. Trace lithium and mental health. J. Neural Transm. 2018, 125, 223-227. [CrossRef]

75. Kessing, L.V.; Gerds, T.A.; Knudsen, N.N.; Jørgensen, L.F.; Kristiansen, S.M.; Voutchkova, D.; Ernstsen, V.; Schullehner, J.; Hansen, B.; Andersen, P.K.; et al. Association of lithium in drinking water with the incidence of dementia. JAMA Psychiatry 2017, 74, 1005-1010. [CrossRef]

76. Liaugaudaite, V.; Mickuviene, N.; Raskauskiene, N.; Naginiene, R.; Sher, L. Lithium levels in the public drinking water supply and risk of suicide: A pilot study. Epidemiology 2017, 43, 197-201. [CrossRef]

77. Nielsen, R.E.; Kessing, L.V.; Nolen, W.A.; Licht, R.W. Lithium and renal impairment: A review on a still hot topic. Pharmacopsychiatry 2018, 51, 200-205. [CrossRef] [PubMed]

78. Khan, K.; Factor-Litvak, P.; Wasserman, G.A.; Liu, X.; Ahmed, E.; Parvez, F.; Slavkovich, V.; Levy, D.; Mey, J.; van Geen, A.; et al. Manganese exposure from drinking water and children's classroom behavior in Bangladesh. Environ. Health Perspect. 2011, 119, 1501-1506. [CrossRef] [PubMed] 
79. Menezes-Filho, J.A.; Novaes Cde, O.; Moreira, J.C.; Sarcinelli, P.N.; Mergler, D. Elevated manganese and cognitive performance in school-aged children and their mothers. Environ. Res. 2011,111, 156-163. [CrossRef] [PubMed]

80. Saritha, K.; Celia, D.A.; Shahryar, H.K.; Nikolay, F.M. Brain deposition and neurotoxicity of manganese in adult mice exposed via the drinking water. Arch. Toxicol. 2014, 88, 47-64. [CrossRef]

81. Bouchard, M.; Laforest, F.; Vandelac, L.; Bellinger, D.; Mergler, D. Hair manganese and hyperactive behaviors: Pilot study of school-age children exposed through tap water. Environ. Health Perspect. 2007, 115, 122-127. [CrossRef] [PubMed]

82. Bouchard, M.F.; Sauve, S.; Barbeau, B.; Legrand, M.; Brodeur, M.E.; Bouffard, T.; Limoges, E.; Bellinger, D.C.; Mergler, D. Intellectual impairment in school-age children exposed to manganese from drinking water. Environ. Health Perspect. 2011, 119, 138-143. [CrossRef] [PubMed]

83. Bauer, J.A.; Henn, B.C.; Austin, C.; Zoni, S.; Fedrighi, C.; Cagna, G.; Placidi, D.; White, R.F.; Yang, Q.; Coull, B.A.; et al. Manganese in teeth and neurobehavior: Sex-specific windows of susceptibility. Environ. Int. 2017, 108, 299-308. [CrossRef] [PubMed]

84. Dion, L.; Saint-Amour, D.; Sauvé, S.; Barbeau, B.; Mergler, D.; Bouchard, M.F. Changes in water manganese levels and longitudinal assessment of intellectual function in children exposed through drinking water. Neurotoxicology 2018, 64, 118-125. [CrossRef]

85. Lee, J.J.; Valeri, L.; Kapur, K.; Hasan, M.O.S.I.; Quamruzzaman, Q.; Wright, R.O.; Bellinger, D.C.; Christiani, D.C.; Mazumdar, M. Growth parameters at birth mediate the relationship between prenatal manganese exposure and cognitive test scores among a cohort of 2- to 3-year-old Bangladeshi children. Int. J. Epidemiol. 2018, 47, 1169-1179. [CrossRef]

86. Frisbie, S.H.; Mitchell, E.J.; Dustin, H.; Maynard, D.M.; Sarkar, B. World health organization discontinues its drinking-water guideline for manganese. Environ. Health Perspect. 2012, 120, 775-778. [CrossRef]

87. United States Environmental Protection Agency. Navajo Nation: Cleaning Up Abandoned Uranium Mines. Available online: https://www.epa.gov/navajo-nation-uranium-cleanup/cleaning-abandoned-uraniummines (accessed on 15 July 2019).

(C) 2019 by the authors. Licensee MDPI, Basel, Switzerland. This article is an open access article distributed under the terms and conditions of the Creative Commons Attribution (CC BY) license (http://creativecommons.org/licenses/by/4.0/). 